\title{
Pleurectomy for persistent pain in benign asbestos-related pleural disease
}

\author{
D I Fielding, J L McKeon, W A Oliver, K Matar, I G Brown
}

\begin{abstract}
Background - Persistent severe pain is a rare complication of benign asbestosrelated pleural disease.

Methods - Four patients are described in whom pain persisted for more than one year (range 18 months to five years) which was incompletely relieved by opioid medication and nerve blocking procedures. All underwent pleurectomy in an attempt to relieve it.

Results - At operation the pleura was considerably thickened in all cases. Two of the four patients had successful relief of pain. The other two had a neuralgic component to their pain before surgery which persisted afterwards. One of these patients underwent successful cervical cordotomy. Conclusions - Pleurectomy may provide relief in patients with constant pleuritic pain due to benign asbestos-related pleural thickening. It seems, however, that patients in whom the pain has a neuralgic component are unlikely to benefit.

(Thorax 1995;50:181-183)
\end{abstract}

Keywords: pleural disease, asbestos, pleurectomy, cordotomy.

Four patients with persistent chest pain due to benign asbestos-related pleural disease are described. The pain did not improve with conventional analgesics so pleurectomy was performed in an attempt to relieve the pain. Pleurectomy for this condition has not previously been described in detail.

Department of

Surgery

K Matar

The Prince Charles

Hospital, Chermside,

Brisbane, Queensland

4032

Department of Medicine, Royal

Brisbane Hospital,

Brisbane, Australia

I G Brown

Reprint requests to: Dr J McKeon.

Received 3 March 1994

Returned to authors

8 June 1994

Revised version received

18 July 1994

Accepted for publication

18 October 1994

\section{Case histories}

The four patients were referred for investigation and treatment of chest pain. Table 1 summarises their clinical features. The pain occurred for several weeks initially, subsided, then became persistent with intermittent exacerbations. It was pleuritic in nature. Two patients experienced superimposed episodes of non-pleuritic pain resembling electric shocks lasting seconds each time for periods of up to two weeks. On physical examination pleural rubs were heard in varying locations in all patients. None had digital clubbing or crackles on auscultation.
Radiological findings and preoperative lung function data are shown in table 2. All patients had progression of their pleural disease - for example, computed tomographic scanning of the thorax in patient 3 in March 1989 showed discrete areas of pleural thickening in the right apex medially and laterally and in the right mid zone and base posteriorly, but in June 1990 continuous right pleural thickening from the apex to the diaphragm was seen posteriorly.

Three patients showed a mild restrictive ventilatory impairment. Serial testing was difficult to perform because of the chest pain. All patients had a raised erythrocyte sedimentation rate up to $44 \mathrm{~mm} /$ hour. Fevers up to $40^{\circ} \mathrm{C}$ occurred in two patients during exacerbations of the pain. Auto-antibody screens were negative in all patients.

All patients had only partial relief from conventional analgesia including opioids in high dose as well as carbamazepine and sodium valproate in the two patients with neuralgic pain. Provision of analgesia was made difficult because of unpredictable exacerbations of the background pain. Opioid medications were used only after adequate trials of non-opioid medication, nerve blocking procedures, and psychiatric assessment. Two patients also received prednisone without benefit. Two patients had transient relief from nerve blocking procedures. Patient 1 had a thoracic epidural block which gave relief for approximately one week. Patient 4 underwent surgical division of the seventh, eighth, and ninth right intercostal nerves after diagnostic nerve blocks gave relief in this area. However, pain recurred in both patients which, in case 4 , was above and below the distribution of the divided intercostal nerves.

Histological examination of open pleural biopsy samples from cases 2 and 4 showed benign pleural plaques.

All patients underwent pleurectomy in an attempt to relieve their pain. Pain was the only indication for operation. Table 3 outlines the operative findings. The lateral chest wall was the predominant site of pleural thickening with less involvement of apical and diaphragmatic pleura. Dissection was made difficult by adherence between lung and visceral pleura in case 1 and between parietal pleura and chest wall in case 2 . In case 4 the right hemi- 
Table 1 Patient details

\begin{tabular}{|c|c|c|c|c|}
\hline & \multicolumn{4}{|l|}{ Patient no. } \\
\hline & 1 & 2 & 3 & 4 \\
\hline Age (years) & 52 & 62 & 44 & 47 \\
\hline Occupation & $\begin{array}{l}\text { Waterside } \\
\text { worker }\end{array}$ & Builder & $\begin{array}{l}\text { Ship's } \\
\text { painter }\end{array}$ & Welder \\
\hline Asbestos exposure (years) & 5 & 30 & 16 & 11 \\
\hline Lag time (years)* & 20 & 20 & 15 & 17 \\
\hline Preoperative pain (years) & 7 & 3 & 2 & 1 \\
\hline Pain site & $\begin{array}{l}\text { Posterior } \\
\text { L }>\mathbf{R}\end{array}$ & $\begin{array}{l}\mathrm{L} \text { base, } \\
\text { axilla }\end{array}$ & $\mathrm{R}$ base & $\begin{array}{l}\mathrm{R} \text { base, } \\
\text { mid zone }\end{array}$ \\
\hline Pleural rubs & Yes & Yes & Yes & Yes \\
\hline Pain type & $\begin{array}{l}\text { Pleuritic } \\
\text { and neuralgic }\end{array}$ & Pleuritic & Pleuritic & $\begin{array}{l}\text { Pleuritic } \\
\text { and neuralgic }\end{array}$ \\
\hline Preoperative treatment (years) & 2 & 2 & 2 & 1 \\
\hline Preoperative pain score $f$ & 7 & $8-10$ & 10 & 9 \\
\hline Postoperative pain scoret & $\begin{array}{l}2 \text { (for } 6 \\
\text { months) now } 10\end{array}$ & 2 & 0 & 9 \\
\hline
\end{tabular}

* Time from last asbestos exposure to development of pain.

† Visual analogue score $0-10 .^{6}$

Table 2 Preoperative investigations

\begin{tabular}{|c|c|c|c|c|}
\hline & \multicolumn{4}{|l|}{ Patient no. } \\
\hline & 1 & 2 & 3 & 4 \\
\hline \multicolumn{5}{|l|}{ Chest radiographs } \\
\hline Localised plaques & $\begin{array}{l}\text { Blunt } \\
\text { costophrenic } \\
\text { angles }\end{array}$ & $\begin{array}{l}\text { (L) Mid zone } \\
\text { (R) Axilla }\end{array}$ & Nil & (R) Base \\
\hline Diffuse thickening & $\begin{array}{l}\text { (R) Upper } \\
\text { zone }\end{array}$ & Both bases & $\begin{array}{l}\text { (R) Apex, } \\
\text { base }\end{array}$ & Nil \\
\hline Transient effusions & No & Yes & Yes & No \\
\hline \multicolumn{5}{|l|}{ CT scans } \\
\hline Localised plaques & Nil & Nil & $\begin{array}{l}\text { (L) Lower } \\
\text { zone }\end{array}$ & $\begin{array}{l}\text { Multiple, } \\
\text { bilateral } \\
\text { all zones }\end{array}$ \\
\hline Diffuse thickening & $\begin{array}{l}\text { Bilateral } \\
\text { to mid zones }\end{array}$ & $\begin{array}{l}\text { Bilateral } \\
\text { to mid zones }\end{array}$ & $\begin{array}{l}\text { (R) } \\
\text { Hemithorax }\end{array}$ & $\mathrm{Nil}$ \\
\hline \multicolumn{5}{|c|}{ Lung function data (with percentage predicted) } \\
\hline $\mathrm{FEV}_{1}(1)$ & $2 \cdot 15(59)$ & $2 \cdot 49(89)$ & $3.94(85)$ & $3.9(118)$ \\
\hline VC (1) & $2.53(51)$ & $2 \cdot 8(78)$ & $4.51(77)$ & $5 \cdot 0(113)$ \\
\hline $\mathrm{FEV}_{1} / \mathrm{VC}(\%)$ & $85(116)$ & $88(144)$ & $87(110)$ & $78(104)$ \\
\hline RV (i) & $2 \cdot 84(148)$ & $1.96(86)$ & $1 \cdot 88(90)$ & $1.89(95)$ \\
\hline $\begin{array}{l}\text { TLC (l) } \\
\mathrm{Kco}(\mathrm{mmol} / \mathrm{min} / \mathrm{kPa})\end{array}$ & $\begin{array}{l}5.21(77) \\
1.94(126)\end{array}$ & $\begin{array}{l}4 \cdot 83(76) \\
1 \cdot 61(111)\end{array}$ & $\begin{array}{l}7 \cdot 27(97) \\
1.57(82)\end{array}$ & $\begin{array}{l}6.07(96) \\
1.44(93)\end{array}$ \\
\hline
\end{tabular}

$\mathrm{FEV}_{1}=$ forced expiratory volume in one second, $\mathrm{VC}=$ vital capacity, $\mathrm{RV}=$ residual volume, $\mathrm{TLC}=$ total lung capacity, $\mathrm{Kco}=$ lung transfer coefficient.

diaphragm was adherent to pleural plaques on the anterolateral chest wall.

In all cases histological examination revealed significant pleural thickening, fibrotic pleural plaques, and chronic inflammatory cell infiltrates. No asbestos bodies were seen. However, the plaques were consistent with asbestos pleural disease. There was no evidence of malignancy. In case 3 the visceral pleura showed fibrous thickening, fibrin exudate, reactive hyperplasia of mesothelial cells, and perivascular lymphocytes and plasma cells.

Patient 1 had partial relief of pain for six months before it recurred. He still has bilateral pain two years after surgery. Patient 2 had permanent relief from pain although in the peroperative period a pleural space infection required reoperation and drainage. Patient 3 had significant improvement in pain but developed mild pain in the opposite hemithorax nine months postoperatively. If this worsens to the extent that he is unable to work he has requested that a second pleurectomy be performed. Patient 4 had relief of pain for six months before it recurred. After a further 12 months he underwent a cervical cordotomy to ablate the left spinothalamic tract. This procedure successfully relieved his pain.

These four cases were performed during a 12 month period and were the only documented cases with this condition known to have undergone pleurectomy by the operating thoracic surgeons in the state of Queensland. They represented 3\% of all pleurectomies performed during this time, the only other indication being recurrent pneumothorax.

\section{Discussion}

Our series is the first to report pleurectomy in this condition. The procedure was successful in two of the four cases. Operative and histological findings demonstrated pleural inflammation. Pain presumably arose from areas where the inflammation came into contact with parietal pleural nerve endings. If the pain was caused by pleural inflammation alone, however, pleurectomy should have abolished the pain in all four cases.

The two patients with persistent pain after pleurectomy had a neuralgic component preoperatively, suggesting that their pain may have been partially explained by intercostal nerve involvement in the inflammatory process. After pleurectomy for any indication there is commonly chest wall discomfort for up to three weeks, whereas these two patients had more persistent pain similar to their original pain. Cordotomy, which is usually indicated for pain of malignant origin, was successful in relieving pain in one of these two patients. ${ }^{1}$

Our four cases of persistent pleural pain due 
Table 3 Operative findings

\begin{tabular}{|c|c|c|c|c|}
\hline & \multicolumn{4}{|c|}{ Patient no. } \\
\hline & 1 & 2 & 3 & 4 \\
\hline $\begin{array}{l}\text { Parietal } \\
\text { pleural } \\
\text { thickening }\end{array}$ & Diffuse & Diffuse & Diffuse & $\begin{array}{l}\text { Multiple } \\
\text { large } \\
\text { plaques }\end{array}$ \\
\hline $\begin{array}{l}\text { Thickness of } \\
\text { parietal pleura (mm) }\end{array}$ & 7 & 5 & 6 & 8 \\
\hline $\begin{array}{l}\text { Visceral pleural } \\
\text { thickening }\end{array}$ & No & No & Yes & No \\
\hline $\begin{array}{l}\text { Adhesions between } \\
\text { visceral and parietal pleura }\end{array}$ & Yes & Yes & No & Yes \\
\hline
\end{tabular}

to benign asbestos-related pleural disease are similar to those previously reported. ${ }^{2-4}$ This condition needs to be distinguished from the more common self-limited episodes of pleural pain which can be associated with benign asbestos-related pleural effusions. ${ }^{3}$ In the series reported by Robinson and Musk ${ }^{3}$ pain lasted for an average of 10 weeks (range 2-26 weeks).

Several features supported an organic basis for our patients' pain. Firstly, pleural rubs in asbestos pleural disease are uncommon ${ }^{5}$ yet they were present in all patients on most reviews. Secondly, increased erythrocyte sedimentation rate and fever were noted. Thirdly, chest radiographs showed progressive changes. Lastly, thoracic nerve blocking procedures and thoracic epidural blocks relieved the pain.

Pleurectomy is therefore unlikely to be helpful for persistent pain due to benign asbestosrelated pleural disease where there is a significant neuralgic component. However, patients without this component who have pleuritic pain which is chronic, debilitating, and not responding to conventional analgesia may respond to the procedure.

1 Stuart G, Cramond T. The role of cervical cordotomy for pain of nonmalignant origin. Med $\mathcal{F}$ Aust 1993;158:667-70. 2 Miller A. Chronic pleuritic pain in four patients with asbestos induced pleurl fibrosic Br $\mathcal{F}$ Ind Med 1990;47:147-53.

Robinson BWS, Musk AW. Benign asbestos pleural effusions: diagnosis and course. Thorax 1981;36:896-900.

4 Hillerdal G. Non-malignant asbestos pleural disease. Thorax 1981;36:669-75.

5 Britton MG. Asbestos pleural disease. Br $\mathcal{F}$ Dis Chest 1982; 76:1-10.

6 Bond MR, Pilowsky I. The subjective assessment of pain and its relationship to administration of analgesics in patients with advanced cancer. $\mathcal{F}$ Psychosomat Res 1966;10:203-8.

\section{Pulmonary vasorelaxant activity of atrial natriuretic peptide and brain natriuretic peptide in humans}

\author{
Robert I Cargill, Brian J Lipworth
}

three study days, MPAP at $\mathbf{T}_{60}$ was lower when ANP $(18 \cdot 3(2 \cdot 0) \mathrm{mm} \mathrm{Hg})$ and BNP $(16.1(1.5) \mathrm{mm} \mathrm{Hg})$ were given concomitantly compared with placebo $(21 \cdot 8$ (1.6) $\mathrm{mm} \mathrm{Hg}$.

Conclusions - These findings indicate that both ANP and BNP exhibit pulmonary vasorelaxant activity in humans in terms of antagonism of the pulmonary pressor effects of angiotensin II. This would support the hypothesis that ANP and BNP act as circulating counter-regulatory hormones in states of pathological pulmonary vasoconstriction.

(Thorax 1995;50:183-185)

Keywords: natriuretic peptides, pulmonary circulation, angiotensin II.

Although the systemic haemodynamic effects of atrial natriuretic peptide (ANP) and brain natriuretic peptide (BNP) in humans are well documented, ${ }^{12}$ relatively little is known regarding their effects in the human pulmonary vascular bed. Both ANP and BNP have been shown to exhibit in vitro pulmonary vaso- 